\title{
A review of the occurrence of Corbicula in the Pleistocene of North-West Europe
}

\section{T. Meijer ${ }^{1} \&$ R.C. Preece $^{2}$}

1 Corresponding author. Netherlands Institute for Applied Geoscience TNO, P.O. Box 80015, 3508TA UTRECHT, the Netherlands; e-mail: t.meijer@nitg.tno.nl

2 Department of Zoology, University of Cambridge, Downing Street, CAMBRIDGE CB2 3 EJ, United Kingdom; e-mail: rcp1001@cus.cam.ac.uk

Received: 1 March 2000; accepted in revised form: 18 April 2000

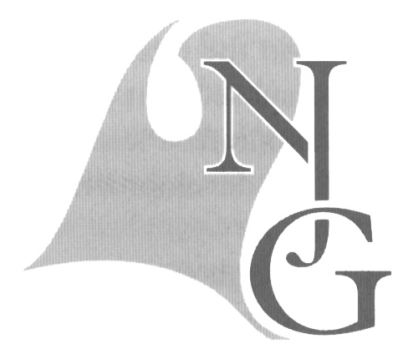

\begin{abstract}
Shells belonging to the bivalve genus Corbicula occur commonly in Pleistocene interglacial deposits in NW Europe. These have usually been identified as $C$. fluminalis, a modern species described from the Euphrates river, although the veracity of this specific attribution remains equivocal. Corbicula has nowadays a southern distribution, and laboratory studies indicate that it is thermophilous. It is also tolerant of brackish water, one of several attributes that make this an effective colonizer.

In NW Europe, Corbicula is known from the Lower Pleistocene but is absent from the Cromerian Complex, occuring again in the three interglacials following the Anglian/Elsterian. It appears to be unknown from the last interglacial, except as derived fossils.
\end{abstract}

Key words: Corbicula, ecology, England, Rhine, Scheldt, Thames, the Netherlands

\section{Introduction}

The bivalve Corbicula fluminalis is perhaps the most famous interglacial mollusc known from North-West Europe. In England, it was first described (as Cyrena trigonula) from Stutton (Suffolk) by S.V. Wood as early as 1834 (Wood, 1834) and it was subsequently discovered as fossils in France, Belgium, the Netherlands, Germany, Austria and Denmark and as far east as Omsk (Kennard \& Woodward, 1922; Von Linstow, 1922). Corbicula has a distinctly southern modern range, occurring in Greece and Sicily (C. gemmellaeii Philippi), and extending from North-East Africa through Syria and Asia Minor to Kashmir (Ellis, 1978). Its occurrence in Pleistocene interglacial deposits of NW Europe was therefore taken to indicate intervals when summer temperatures were higher than those of today.

Despite being such a well known Pleistocene fossil, a number of important questions about Corbicula have never been answered satisfactorily. The first concerns its exact identity and the question of whether the Pleistocene fossils are really conspecific with Corbicula fluminalis (Müller, 1774) described from the Euphrates river. The second, obviously related to the first, concerns its ecology and the palaeoclimatic inferences that can legitimately been drawn from its presence and whether it can tolerate mildly brackish water. The third question concerns its geological history and whether its occurrence can be used to distinguish interglacials of different ages.

The aim of the present contribution is to review the occurrence of Corbicula in the Pleistocene of NW Europe and to address each of the above questions.

\section{Systematics of Pleistocene Corbicula in NW Europe}

Photographs of a co-type of Müller's Tellina fluminalis from the Euphrates, preserved in the Zoological Mu- 
seum of the University of Copenhagen, have been published by Kennard \& Woodward (1926: plate 9, figs. $4 a-d)$. These show a rather narrow shell with prominent umbos that can be matched exactly in form and sculpture with examples of Corbicula from the European Pleistocene. The British shells show great variation, sometimes being rather thin and compressed, with relatively small umbos and a broad shell; at other times, they may be thick and robust, tumid, with strong, prominent umbos and a shell that is more trigonal and taller in proportion to its breadth (Fig. 1). Thicker shells tend also to have a stronger, more regular sculpture. Such variation is probably controlled largely by the environment. The flatter, broader shells, which may attain a large size, are mainly found in fine sands and silts, whereas the thicker shells tend to occur in the coarser, more gravelly deposits of open rivers. Considerable variation is commonly found, however, among series of shells from a single site.

Connolly (1930: 43) considered that modern Corbicula fluminalis from the Euphrates differed specifically from the commonest form of Corbicula living in the Nile, to which he applied the name $C$. consobrina (Cailliaud, 1823). He claimed that C. fluminalis sensu stricto was characterized by its narrow shell, deflected umbos, and relatively coarse sculpture, whilst $C$. con- sobrina could be distinguished by its broader shell, less prominent umbos and finer sculpture. Connolly observed, however, that true $C$. fluminalis probably occurred in Egypt under the name of C. artini Pallary, 1902. Gardner (1932), in a comprehensive study of the recent and fossil molluscs from the Fayum Depression, figured series of both $C$. consobrina and $C$. artini from that area. Her figures show that intergradation takes place between the two taxa and that intermediate forms occur (Gardner, 1932: pl. 7, fig. 234). Despite this, she retained the trivial names consobrina and artini for the two extremes. Gardner observed that English Pleistocene Corbicula specimens are comparable to $C$. consobrina, rather than to $C$. arti$n i$, but she was apparently familiar only with shells from the Cambridge area. Baden-Powell (1934) subsequently applied the name $C$. consobrina to English Pleistocene material in general.

This usage does not appear to be well founded: in most large series of Corbicula from the English Pleistocene a complete intergradation occurs, as in Egypt, between tall, thickened artini or fluminalis types and broader, thinner consobrina types. A similar variation is typical of other fresh-water bivalves, such as members of the genera Pisidium and Sphaerium, and is controlled by the nature of the environment.

Laville (1898) similarly noted that specimens of

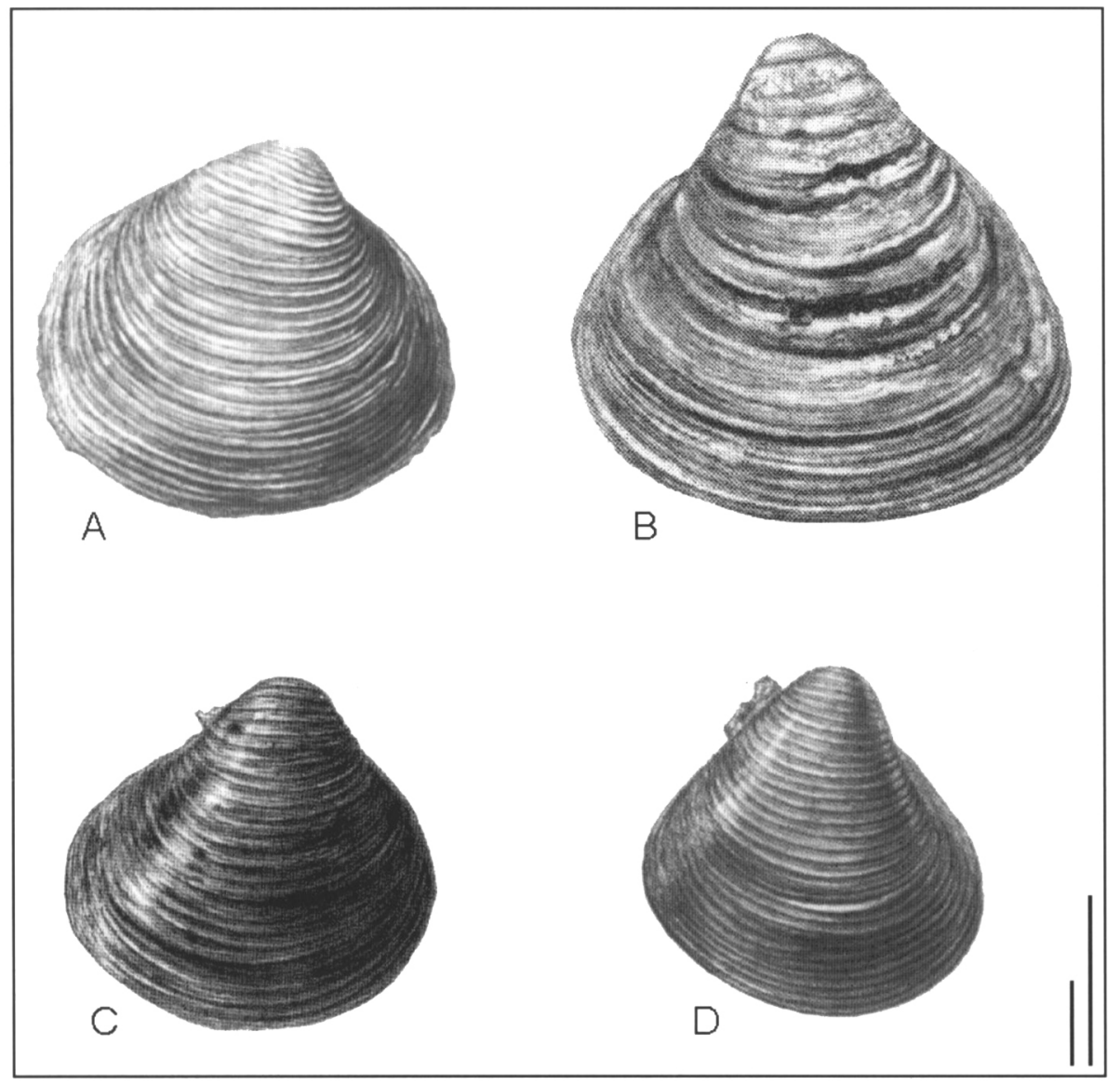

Fig. 1. Variation of Corbicula from NW Europe. All specimens come from the Netherlands. Scale: bar is $5 \mathrm{~mm}$, A: long bar, B-D: short bar. Artist: G. Peeters, Schiedam, The Netherlands.

A: C. fluminalis s.l, wide form (Pleistocene).

B: C. fluminalis s.1., elongate form (Pleistocene).

C. C. fluminea (Müller, 1774) (Modern).

D. C. fluminalis (Müller, 1774) (Modern). 
Corbicula from Cergy (France) can be divided into two groups, one with thin shells and the other with thick. Two specimens of the latter type resemble var. cor Lamarck, as do specimens from the March gravels mentioned by Dollfus (1884).

Many authors therefore consider $C$. consobrina to be only a subspecies or race of the Asiatic $C$. fluminalis and some populations from the lower Nile and Lake Tana are morphologically inseparable. According to Van Damme (1984), however, most Sudanian populations do differ, indeed, from C. fluminalis s.s. but show much variation, which might indicate the existence of several strains. Van Damme retained the name consobrina for the Sudanian species, noting the existence of four fundamental forms that are linked through a series of intermediates, possibly just reflecting ecophenotypic variation.

Populations have rarely been studied within the natural range of the genus. Morton (1986), after consideration of ecological, physiological, population and reproductive data from China and Japan, reaffirmed that only two species of Corbicula (fluminea and fluminalis) occurred throughout Asia. According to Britton \& Morton (1986), the two taxa are difficult to distinguish by shell morphology when young, but adult specimens of $C$. fluminalis ( $>1$ year) bear more deeply impressed growth lines and more widely spaced sulcations on the shell exterior and tend to be taller (less elongate) than C. fluminea.

\section{Corbicula in the Netherlands}

Corbicula was recently introduced to the Netherlands (Blanken, 1990). Initially only one form seemed to be present, but later two distinctive forms were distinguished, which spread more or less simultaneously. Both forms are now considered to be separate species, although initially confusion existed about the correct names that should be applied. Kinzelbach (1991) called them C. fluminea and C. fluviatilis but Moolenbeek (1993) subsequently demonstrated that the proper names for these taxa should be $C$. fluminea and $C$. fluminalis. These recent species are probably not conspecific with the Quaternary fossil, C. fluminalis, which is, as stated above, also polymorphic. Meijer (in Gittenberger et al., 1998) observed a large difference in the sculpture of the juvenile shell of fossils and the two recent species in the Netherlands. Juvenile shells of $C$. fluminea, as well as $C$. fluminalis, are far more coarsely ribbed than any fossil Corbicula shell known from the Netherlands. Gittenberger et al. (1998) therefore consider both forms of the fossil species as a distinct taxon, the status of which is as yet unknown, but the present authors consider that the taxonomic status of fossil, as well as recent, species remains unresolved. The taxonomy cannot be resolved within the scope of this limited review, so the widely used name $C$. fluminalis will be retained here for the European Quaternary fossils.

\section{Ecological and palaeoclimatic significance}

Corbicula is a notorious colonizer that can occur in such numbers as to be a pest of potable and industrial water-supply systems. The genus has spread widely through the waterways of North America and many ecological studies, aimed primarily at controlling it, have been undertaken in recent years (e.g., Britton \& Morton, 1979). Although absent from the Holocene in NW Europe, the genus has recently been introduced into this region (Mouthon, 1981). In the Netherlands, for example, it invaded many Dutch rivers within only a four-year period (Blanken, 1990; Kinzelbach, 1991). Den Hartog et al. (1992) considered the reasons why this invasion of the Rhine had been so successful. They pointed out that both Corbicula and an amphipod, Corophium curvispinum, that invaded the Rhine at the same time, are $r$-strategists and are consequently able to respond opportunistically when circumstances become favourable. The properties of rapid growth, production of several generations per year, early maturity and considerable fecundity are ideal attributes for a successful colonizing species.

C. fluminalis would presumably have behaved in a similar fashion during the Pleistocene, invading and spreading rapidly through river systems following initial colonization. What is clear is that Corbicula can live both in fluvial sands and gravels in relatively highenergy environments and in silts and muds in quieter habitats, the variation in shell morphology probably reflecting these environmental differences. The genus is known from Africa from some of the larger lakes, such as Lake Chad (Van Damme, 1984).

One outstanding issue is whether Corbicula can tolerate brackish water. Baden-Powell (1934) was specifically interested in this question in his paper on the March gravels in Cambridgeshire. He noted that smaller specimens of Corbicula from fluvial sediments near Cambridge, such as those from Barnwell, had a smaller height in proportion to their length than the smaller specimens from the 'marine bed at Manea' ( $p$. 207 ). Although he considered the possibility that the Corbicula in the March gravels had been derived 'from the Cambridge district', he thought it more probable that it had 'adapted itself to life with the marine forms, in spite of the cold conditions under which they lived' (p. 212). Such a conclusion now seems un- 
likely in view of the extent of re-working that has occurred in the Fenland (see also West et al., 1994). Corbicula occurs in many North Sea boreholes together with Cerastoderma glaucum and Macoma balthi$\mathrm{ca}$, which both tolerate lowered salinities. The observation that the number of Corbicula specimens decreases when more euhaline species occur, shows that the Pleistocene species was tolerant of brackish conditions (T. Meijer, unpubl. data). The extant C. fluminea has been recorded in brackish sections of estuaries and is definitely salt-tolerant (up to $14 \mathrm{ppt}$ ), and occurs in the Netherlands in greatest densities in the tidal area of the river (Den Hartog et al., 1992). Similar observations were reported from elsewhere (Mienis, 1991). Britton \& Morton (1986), reviewing Asian data, observed that $C$. fluminalis is usually found in the brackish lower reaches of river mouths (in salinities up to $24 \mathrm{ppt}$ ).

A second ecological issue concerns the palaeoclimatic inferences that can be drawn from the occurrence of Corbicula in the European Pleistocene. It might have been tempting, purely from its southern range, to exaggerate the contemporary mean annual temperatures but it is clear, when the whole associated biota is considered, that these were only $1-2^{\circ} \mathrm{C}$ above present-day values during the middle part of the interglacial. Observations on $C$. fluminea show that juveniles grow fast at $25^{\circ} \mathrm{C}$ (about $1 \mathrm{~mm}$ a week), that growth stops below $15^{\circ} \mathrm{C}$, and that considerable mortality results within 1 week at $0^{\circ} \mathrm{C}$, so that the population may decrease in cold water (Den Hartog et al., 1992).

In a review of molluscs from the 'last interglacial', in SE England, Sparks (1964) pointed out the contrast between the delayed arrival of thermophilous species, such as Corbicula, at the beginning of the interglacial and their persistence towards its end, when climatic conditions showed clear signs of deterioration. This situation was particularly clear at Stutton (Suffolk), where fluvial conditions remained relatively uniform; there was nevertheless a steady decline in southern taxa, especially Corbicula, towards the end of the interglacial (Sparks \& West, 1964). Such evidence serves as a warning against the uncritical assumption of thermal optimum conditions whenever Corbicula is found as a fossil, even in situations where derivation can be excluded.

\section{Geological history}

The earliest European record of $C$. fluminalis appears to be a Late Pliocene record from Montagny-lesBeaune (France) (Schlickum et al., 1978), where it occurred with Corbicula trigona (Tournouër). A record from the Red Crag at Waldringfield, in East Anglia (Bell, 1871), may be an error since the specimen cannot be traced. There are, however, several records from the Norwich Crag in East Anglia (Nyst, 1838) described his duchasteli from Norwich Crag specimens. It is known from a number of localities in the Netherlands, ranging in age from the Tiglian to the Leerdam interglacial (Tesch, 1929a,b, 1944; Spaink, 1968; Meijer, 1987, 1988a, 1990). Corbicula is not known from the 'Cromerian Complex' of either England or the Netherlands. All the published records of it from the British Cromer Forest Bed Formation are based on misidentifications (Meijer \& Preece, 1996).

The record of Corbicula in NW Europe after the Anglian/Elsterian is an important issue to clarify. Until relatively recently, interglacial deposits following this major glacial stage have been assigned to one of two temperate stages, namely the Holsteinian/Hoxnian or the Eemian/Ipswichian. It is clear from a consideration of not only the marine oxygen-isotope record (Shackleton \& Opdyke, 1973) but also palynological records from long lacustrine sequences (Tzedakis et al., 1997) that the situation is more complex than this, and that at least four interglacials preceding the Holocene have occurred since the Elsterian/Anglian. These have been assigned to oxygen-isotopes stages $11,9,7$ and substage 5 e respectively, although these correlations - except for the last interglacial (5e) - are inferred rather than firmly established (cf. Sarntheim et al., 1986). Recent amino-acid analyses from the Netherlands indicate that a correlation with oxygen-isotope (sub) stages $9,7 \mathrm{c}, 7 \mathrm{a}$ and $5 \mathrm{e}$ is another possibility (Meijer \& Cleveringa, in prep.).

The published records of Corbicula from interglacials after the Elsterian/Anglian therefore need to be evaluated critically. Such a comprehensive review cannot be undertaken within the constraints of the present contribution, but the history of $C$. fluminalis can be elucidated for two critical regions, southern England and the Netherlands.

\section{Southern England}

Two views have emerged recently concerning the Pleistocene succession of deposits laid down by the Thames river. Gibbard $(1994,1995)$ attributed all known interglacial sites in the lower Thames area, with the exception of Swanscombe, to the last interglacial. Bridgland $(1994 ; 1995)$, on the other hand, proposed a model in which the terraces in the London area are represented by sandwiches of sediment representing cold/warm/cold climatic sequences, with downcutting between terraces also occurring during 
(actually near the beginning of) cold periods. This model requires that the temperate-climate sediments of different terraces represent different interglacials. Four separate interglacials within the staircase of terraces in the London area were thus recognized (Fig. 2). The oldest of these occurs at Swanscombe and is believed to be Hoxnian (= Holsteinian). The second interglacial occurs beneath the terrace formed by the Lynch Hill/Corbets Tey Gravel and has been recognized at Belhus Park (Gibbard, 1994), Purfleet (Allen, 1977; Hollin, 1977) and Grays (Hinton \& Kennard, 1900; Kerney, 1959). The penultimate interglacial occurs at a number of sites formed by the Taplow/Mucking Gravel, including Ilford (Uphall Pit), Aveley, West Thurrock and Crayford. Regardless of the ages attributed to each interglacial, the terraces of the Thames provide a useful stratigraphical framework against which to assess the history of Corbicula. Since Britain is situated on the western margins of Europe, the history of Corbicula here is likely to reflect that of NW Europe generally, assuming that Corbicula did not reach Britain by spectacular 'jump dispersal'.

Corbicula is absent in the earliest interglacial sediments deposited by the Thames after its diversion into its present valley during the Anglian stage. These deposits, the so-called 'Lower Gravel' and 'Lower Loam', which both contain temperate molluscs, occur at Barnfield Pit (Swanscombe, Kent) (Kerney, 1971).
Corbicula does occur higher in the same sequence in the Middle Gravel, however. The sediments at Swanscombe have been oxidized and are generally devoid of pollen. Those at Clacton-on-Sea (Essex), however, which are believed to be contemporaneous with those at Swanscombe, are organic and have yielded pollen. This has enabled them to be related to several substages of the interglacial (Turner \& Kerney, 1971). As at Swanscombe, Corbicula is absent from the earliest fresh-water deposits at Clacton and occurs only, as drifted valves, in the estuarine beds that formed during the late temperate substage (Ho IIIb). Kerney (1971) used this evidence to suggest that the Lower Gravel and Lower Loam at Swanscombe formed during the early temperate substage (Ho II), whereas accumulation of the Middle Gravel did not begin before the end of the late temperate substage (Ho III). The deposits at both Swanscombe and Clacton are believed to have formed during OIS 11 (Bridgland, 1994), a suggestion that has recently received support from uranium-series dating of authigenic carbonates at classic Hoxnian sites such as Marks Tey (Essex) (Rowe et al., 1999). At a new locality $20 \mathrm{~km} \mathrm{SW}$ of Clacton, at East Hyde (Tillingham, Essex), Corbicula has also been discovered in tidally influenced fluvial sediments from the later part (Ho IIIb) of this interglacial (Roe \& Preece, 1995; Roe, 1999).

Deposits from four sites in the Thames system seem to have formed during the subsequent inter-

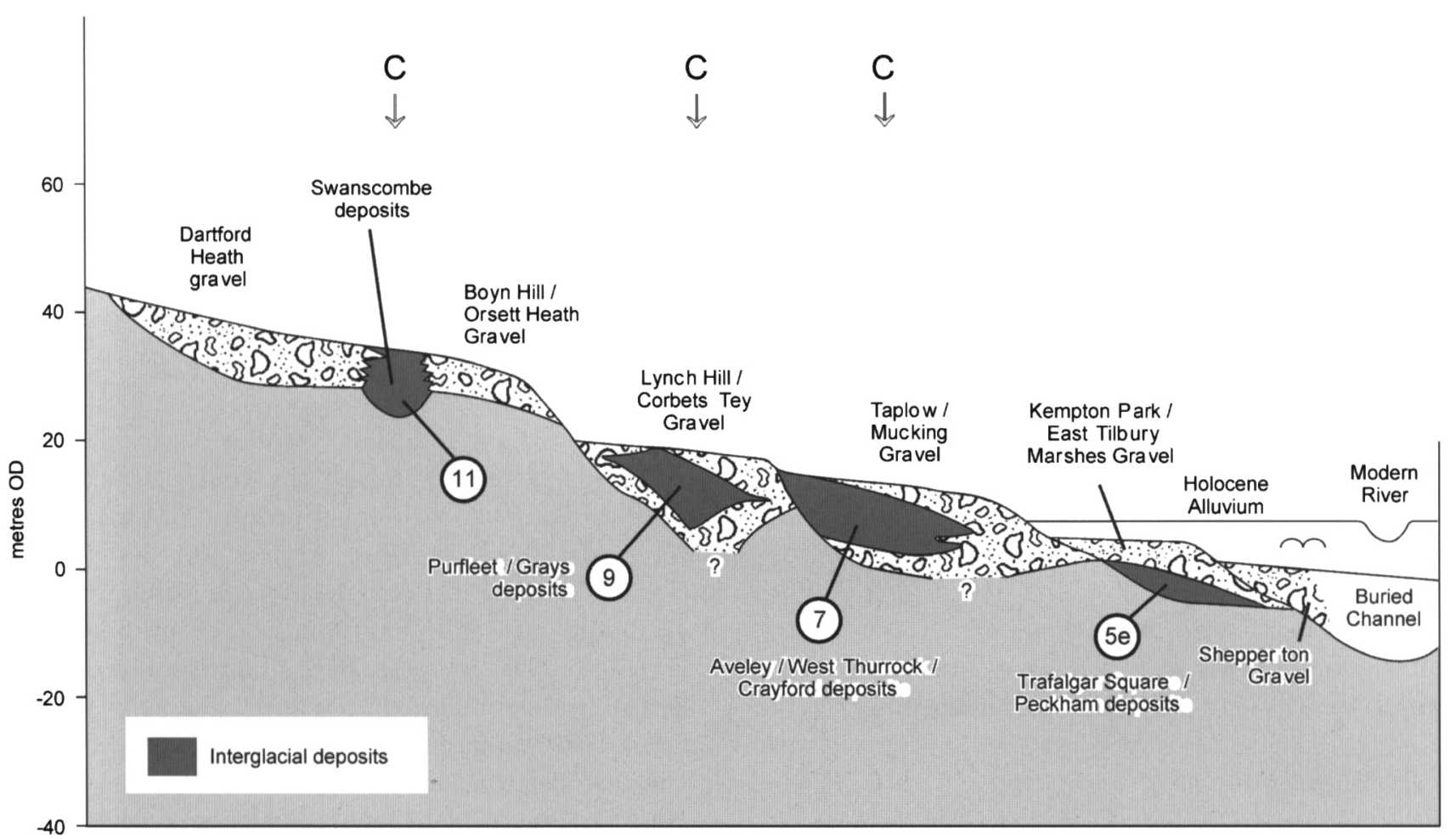

Fig. 2. Idealized transverse section through the terraces of the lower Thames (modified from Bridgland, 1994). The circled numbers are oxygen-isotope stages with which these deposits have been correlated. Terraces with Corbicula are indicated with ' $\mathrm{C}$ '. 
glacial, represented at Belhus Park, Hackney Downs, Grays and Purfleet. There are two further sites in Essex: Barling, which is situated in the lower reaches of the present Thames valley, and Cudmore Grove, located to the North-East, in eastern Essex, which probably represents a tributary (Bridgland, 1995; Roe, 1999). Only a sparse vertebrate fauna is known from Barling but the vertebrate assemblages from the other sites are remarkably similar, though different in a number of important respects if compared to those from earlier (i.e., those from OIS 11) and later deposits (Schreve, 1997). Corbicula is known from each of these sites; at Barling it occurs in tidally influenced sediments formed during the early part of the interglacial (Bridgland et al., submitted). Such evidence reinforces the view that the sediments from these sites are different in age from those at Swanscombe and Clacton.

Discrimination of sediments belonging to the next two interglacial stages (i.e., the penultimate and the last interglacial) has been a source of much debate that has not yet been finally resolved. It has been noted in recent years that Corbicula never occurs in Britain in sediments containing Hippopotamus (see, among others, Keen, 1990; Bridgland, 1994), although there are a few early reports claiming the contrary. It is important now to discuss each of these in turn. In the upper Thames, where both taxa occur separately - within the sequence underlying the Summertown-Radley Terrace, their mutual exclusion is particularly obvious (Bridgland, 1994). Sandford (1925) believed, however, that both species could be found in the upper part of the Summertown-Radley sequence, later termed the 'Eynsham Gravel' (Briggs et al., 1985). Bridgland noted that Hippopotamus was never found in supposed Eynsham Gravels yielding Corbicula, with the exception of Radley, where the bivalve was represented by a single abraded shell (Kennard \& Woodward, 1924), probably reworked. He concluded that the deposits in which Corbicula was abundant were older and correlated with the lowermost channel-fill deposits of the SummertownRadley sequence at Stanton Harcourt (Buckingham et al., 1996). Eynsham itself, where the fauna clearly comes from the uppermost Summertown-Radley deposit, is a Hippopotamus site, so the term Eynsham Gravel can still be applied to that part.

Another valley from which it has been claimed that Hippopotamus and Corbicula occur together is the Cam, in Cambridgeshire. Marr (1917) reported their occurrence in basal loam deposits of what was later referred to the ' 2 nd $T e r r a c e$ ' of the Cam, at Barnwell and near Chesterton (Worssam \& Taylor, 1969). Elsewhere the Cam $2^{\text {nd }}$ Terrace has produced faunal as- semblages suggestive of mixtures from sediments of different ages, probably including those from the celebrated site at Barrington, although the terrace there has not been assigned to the Geological Survey's numbered sequence. Barrington is another site from which both Hippopotamus and Corbicula are recorded, but it appears that the record of the latter is based on just three fragments (Kennard \& Woodward, 1919); as at Radley, these may well have been reworked. The records from the Cam were part of the basis for Tomlinson's (1925) suggestion that the 'HippopotamusCorbicula fauna', subsequently assumed to typify the Ipswichian (a.o., Shotton et al., 1977), was represented in the terraces of the Warwickshire Avon, even though the Hippopotamus occurs there in deposits of Terrace 3 and the Corbicula in deposits of Terrace 4 (Maddy et al., 1991).

In the middle Thames, Hippopotamus has been found at Trafalgar Square in central London, but Corbicula is absent in what appears to have been an entirely suitable environment (Preece, 1999). As both taxa are today commonly associated in African rivers such as the Nile, there seems to be no obvious ecological reason for this interglacial pattern of occurrence. Many workers in Britain now believe that deposits containing Hippopotamus are different in age from those yielding Corbicula. Since Hippopotamus is regarded as an indicator species for the last interglacial in Britain (Sutcliffe, 1964, 1995; Stuart, 1976), the Corbicula-bearing sediments are thought to be preIpswichian.

Corbicula occurs at a number of sites in the lower Thames that would seem to be younger than those of the first two post-Anglian interglacials already mentioned. Several of these, such as Ilford (Uphall), Crayford and Aveley, have previously been attributed to the last interglacial, largely on pollen-analytical evidence (Sparks, 1964; West et al., 1964; West, 1969; Gibbard, 1994). Fluvial sequences invariably yield fragmentary pollen records, however, covering only parts of an interglacial, and these can be hard to interpret biostratigraphically. Not only are there taphonomic problems relating to the pollen source area, but reworking can be a major problem in fluvial environments. Moreover, most of these correlations were made before the real complexity of the stratigraphical succession was fully appreciated. The basis of such correlations has therefore been questioned on a number of grounds including terrace stratigraphy (Bridgland, 1994), aminostratigraphy (Bowen et al., 1989) and vertebrate palaeontology (Sutcliffe, 1964, 1975, 1976; Schreve, 1997). This evidence suggests that these sites belong to a pre-Ipswichian interglacial, possibly equivalent to OIS 7 . 
There is a consensus, however, about the correlation of sites beneath the Kempton Park terrace (= Isleworth terrace), such as Trafalgar Square (Gibbard, 1994; Preece, 1999) and Brentford (Zeuner, 1959; Kerney, 1959), with the Ipswichian (= Eemian). Hippopotamus remains occur at both sites but Corbicula is unknown. When evaluating the ages of particular sites, it is vital not to rely solely on stratigraphical 'indicator species' because of the danger of circular reasoning. Reworking can also be a serious problem, particularly in fluvial contexts. For example, Hippopotamus remains occur, not infrequently, in all Devensian gravel aggradations of the Thames (Gibbard, 1994) and Corbicula shells are also frequently present but in a reworked state (cf. West et al., 1994).

Corbicula is a common fossil in Thames deposits but its occurrence is sporadic and not ubiquitous. If Gibbard is correct and all the interglacial deposits except Swanscombe - in and East of London are Ipswichian then this fact is awkward to explain. Since Corbicula is such an invasive species, its occurrence at nearby sites in the same valley would be expected, particularly since they all represent similar fluvial facies. Its absence at sites like Trafalgar Square appears to be significant, given the large number of shells analysed (Preece, 1999). Other mollusc species have geological histories similar to that of Corbicula in the Thames system. Pisidium clessini (= astartoides auctt.), for example, also occurs in the later part of the Swanscombe aggradation (Kerney, 1971) and in interglacial deposits attributed by Bridgland to two different post-Hoxnian/pre-Ipswichian interglacials, but not in those of substage $5 \mathrm{e}$. This evidence supports the view that Trafalgar Square belongs to a different interglacial than the other Corbicula-bearing sediments in the lower Thames (Preece, 1995).

Assuming Bridgland's (1994) stratigraphy to be correct, the conclusion is that, in the Thames area, Corbicula was present in each of the first three interglacials after the Anglian (i.e. those tentatively correlated with OIS 11,9 and 7) but that it was absent in the Ipswichian (OIS 5e) and the Holocene. If this situation can be shown to be true for other regions as well, the occurrence of Corbicula may have important biostratigraphical significance for differentiating lastinterglacial sites from earlier ones.

\section{The Netherlands}

Corbicula fluminalis is known from deposits of Middle and Late Pleistocene age from the South-Western part of the Netherlands (Van der Sleen, 1912; Lorié, 1913; Steenhuis, 1915, 1919). Most of the specimens collected by Van der Sleen cannot be traced, and their identification cannot be verified, although it is known that he incorrectly identified Spisula subtruncata as Corbicula. The observations by Lorie and Steenhuis may well have been correct since their sites are in the area from which later investigations unambiguously showed the presence of Corbicula. Lorie (1913) was aware of the significance of this species and he referred to its pre-Eemian occurrence in the surrounding countries, but as he found it in only two boreholes with a poor sample resolution, he left open the question of its stratigraphical range in the Netherlands. These Corbicula-bearing deposits subsequently became known as the 'Schouwen Formation' (cf. Van Rummelen, 1970), which can be considered as the northern extension of the infill of the 'Flemish Valley'. The age of this formation has been the subject of much debate. Tesch (1939) regarded the deposits as a 'marine intercalation in the High Terrace', which is of Middle Pleistocene age. This conclusion was based mainly upon the comparable depth of nearby Middle Pleistocene fluvial deposits and on the similarity of the marine molluscan assemblages with those of borehole 6D38-Noordbergum (Meijer \& Preece, 1996) in the northern part of the Netherlands, which were thought at the time to be of Holsteinian age. As at Noordbergum, the molluscan assemblages in the Schouwen Formation have a low diversity, with Cerastoderma edule being dominant. The presence of Saalian till above the marine deposits in the Noordbergum area was another important reason for their attribution to the Middle Pleistocene. Bennema \& Pons (1952) subsequently assigned the Schouwen Formation to the Eemian, again on the basis of the marine molluscs and its comparable depth to the marine Eemian deposits in the central part of the Netherlands. They were not impressed by the similarities between these molluscan assemblages and those from Noordbergum and they stressed the similarity with the marine assemblages of the Eemian type area. Subsequently, Van der Heide (1957) thought that these Schouwen deposits ranged in age from the late Eemian to the Early Weichselian, invoking reworking of marine deposits during the latter interval.

De Jong \& Zagwijn (1983) and De Jong (1988) suggested the presence of Eemian sediments in the Schouwen Formation on the basis of palynology. Contrary to De Jong (1988), however, De Jong \& Zagwijn (1983) found a chaotic 'succession' of pollen zones, indicating reworking of the entire deposit, probably during a late phase of the Eemian or during the Weichselian. This led to the conclusion that all marine deposits in the Schouwen Formation were reworked during the Weichselian (De Gans \& De Groot, 1995a,b), a conclusion that is certainly incor- 
rect. Extensive reworking of the Schouwen Formation has occurred, probably during the Weichselian, but undisturbed estuarine and shallow-marine deposits belonging to this formation also occur.

Several aspects of the molluscan evidence of the Schouwen Formation have always been under-valued, especially the presence of certain non-marine species in the marine assemblages. The occurrence of two fluvial prosobranch species seems to be particularly important. Theodoxus fluviatilis has its first occurrence in NW Europe in the Eemian (Meijer, 1988b), and is common in the marine deposits of the Eemian type area, where it has been supplied by the Rhine. T. fluviatilis has never been found together with Corbicula nor with any fluvial species, such as Pisidium clessini, thought to characterize pre-Eemian interglacial deposits. A related species, Theodoxus danubialis (= cantianus of British authors) - often mistakenly identified as T. fluviatilis - has never been found in the Eemian of NW Europe. It is known from several Middle Pleistocene sites, including Swanscombe and Tillingham near East Hyde (England), Herzeele (France), Izenberge, Beveren, Gyverinckhove and Vinkem (Belgium), Berlin, Bilzingsleben and Mosbach (Germany) (Meijer, 1988b; Meijer \& Preece, 1995). At Zelzate, in Belgium close to the Dutch border, Janssen (1965) found T. fluviatilis in Schouwen deposits associated with several 'characteristic' marine Eemian species, such as Venerupis aurea senescens and Bittium reticulatum, together with Corbicula fluminalis. Zagwijn \& Paepe (1968) demonstrated the presence of an interglacial soil, which they regarded as the Eemian Rocourt soil, in relation to the marine beds. Meijer (1969) showed that this T. fluviatilis was, in fact, $T$. danubialis, which gave rise to serious doubts about the stratigraphical interpretation of, at least part of, this sequence. In a neighbouring Dutch borehole (54A34-Bakkersdam), T. danubialis and Corbicula were associated, together with Eemian, Late Pliocene and Eocene marine species in a deposit probably reworked during the Weichselian. In other sites in the Flemish valley, Belgian authors reported the regular association of T. fluviatilis and Corbicula (De Breuck et al., 1970; De Moor \& Heyse, 1975), but their identification of $T$. fluviatilis is highly questionable and has not been verified.

At borehole 37C554-Zuurland, the Schouwen Formation could be divided into several units (Van Kolfschoten \& De Boer, 1988). The upper part was assigned to the Eemian on the basis of palynology (De Jong, 1988) and molluscs (Meijer, 1988a: zones DE). Several 'typical' marine Eemian molluscan species are present, as well as Theodoxus fluviatilis. Corbicula also occurs, but only as abraded shells, suggesting re- working. In the lower part of the Schouwen Formation, below the marine Eemian deposits, a coarsegrained sediment with a basal gravel occurs (molluscan zone F). This is underlain by finer-grained sediments yielding a species-poor marine assemblage lacking typical Eemian species (molluscan zone G) but containing well preserved specimens of Corbicula and Pisidium clessini, indicating a pre-Eemian age. It therefore appears that two interglacials are present in this borehole through the Schouwen Formation: the Eemian above and a Middle Pleistocene interglacial below. A similar situation was found in a nearby borehole (37E486-Oude Leede). Outside the depositional area of the Schouwen Formation, Corbicula is known from several other sites, including a borehole at Noorderhoeve (19E117), whereas, Corbicula was found in a Middle Pleistocene fluvial assemblage, below Saalian till, in the Eemian type area. Above the till a characteristic marine Eemian assemblage was recovered in which several non-marine species were present but not Corbicula.

In the Belvédère pit, near Maastricht, interglacial deposits yielding a Middle Palaeolithic industry are present on top of the Caberg-3 terrace of the Meuse river (Van Kolfschoten \& Roebroeks, 1985; Vandenberghe et al., 1993; Van den Berg, 1996). All deposits were devoid of pollen, but rich assemblages of vertebrates and molluscs are present. Corbicula occurs at various sites in the pit, more or less at the same level as the interglacial (Meijer, 1985). Thermoluminiscence dates on burnt flint provided an age of $250 \pm$ $20 \mathrm{ka}$, which was supported by an ESR date on shells of $220 \pm 40 \mathrm{ka}$. Amino-acid analyses on Corbicula gave a mean $\mathrm{D} / \mathrm{L}$ ratio of $0.388 \pm 0.014$ (Table 1 ). Vertebrates indicate a post-Holsteinian and preEemian age (Van Kolfschoten, 1985, 1993). Indeed, Van Kolfschoten et al. (1993) consider the interglacial to be intra-Saalian, most probably a correlative of the Early Saalian Hoogeveen interstadial, which they consider to be equivalent to OIS 7 .

The sand pit of Fransche Kamp near Wageningen is in the ice-pushed area of the Veluwe (Ruegg, 1991). Ice-pushed Middle Pleistocene deposits in this pit yielded molluscan assemblages including Corbicula at several levels (Meijer, 1991). Pollen analyses of clayey sediments indicated a Middle Pleistocene interglacial but this was difficult to assign, although the presence of a prominent peak of Tilia may be significant. The vertebrates suggested correlation with the Belvédère interglacial and to an age older than a micromammal assemblage recovered from a nearby pit (Leccius de Ridder) at Rhenen, where interglacial deposits, also pushed by Saalian ice (Ruegg \& Zandstra, 1981), have yielded a micromammal and non-marine mol- 
Table 1. Amino-acid analyses. Mean D/L ratios from several critical sites in the Netherlands, arranged in relation to D/L ratio of $M a c o m a$ balthica.

First column: site names with NITG site identification and depth in metres below Dutch Ordnance Datum. Second and third columns: D/L ratios with standard deviation, number of analyses and laboratory code. AAL = Colorado amino-acid laboratory (INSTAAR, Boulder, USA); ABER = amino-acid laboratory of the University of Wales at Aberystwyth (UK). UKAL = amino acid laboratory of the University of Wales at Cardiff (UK). Age: E = Eemian; LMP = late Middle Pleistocene interglacial; B = Belvédère interglacial.

\begin{tabular}{|c|c|c|c|}
\hline \multirow[t]{2}{*}{ site } & \multicolumn{2}{|l|}{ mean $\mathrm{D} / \mathrm{L}$. ratios } & \multirow[t]{2}{*}{ age } \\
\hline & Corbicula fluminalis & Macoma balthica & \\
\hline 19C648-Castricum, 34-35.50 m & - & $0.162 \pm 0.016[4](\mathrm{AAL}-4223)^{1}$ & $\mathrm{E}$ \\
\hline 19C648-Castricum, 41-42 m & - & $0.165 \pm 0.020[4](\mathrm{AAL}-4227)^{1}$ & $\mathrm{E}$ \\
\hline 37C554-Zuurland, $27-28 \mathrm{~m}$ & - & $0.178 \pm 0.039[5]($ ABER-1245) & $\mathrm{E}$ \\
\hline 19A263-Bergen, 66-67 m & - & $0.179 \pm 0.017[4](\mathrm{AAL}-3386)^{1}$ & $\mathrm{E}$ \\
\hline S01-113 (North Sea), 3-5 m & - & $0.194 \pm 0.004[2](\mathrm{ABER}-1250)$ & $\mathrm{E}$ \\
\hline 15H57-Creil, 14.66-15.35 m & - & $0.198 \pm 0.015[3](\mathrm{UKAL}-105 / 107)$ & $\mathrm{E}$ \\
\hline \multirow[t]{2}{*}{ 19C648-Castricum, $34-35.50 \mathrm{~m}$} & $0.244[1](\mathrm{AAL}-4815)$ & $0.216 \pm 0.060[4](\mathrm{AAL}-4224)^{1}$ & ?LMP \\
\hline & & $0.210 \pm 0.030[3](\mathrm{AAL}-4429)$ & \\
\hline 37C554-Zuurland, 30-32 m & $0.301 \pm 0.012[4](\mathrm{UKAL}-251)$ & $0.245 \pm 0.035[3]($ ABER-1246) & $\mathrm{LMP}$ \\
\hline 6A53-Janum, $23 \mathrm{~m}$ & - & $0.290 \pm 0.024[3](\mathrm{UKAL}-195)$ & LMP \\
\hline Zelzate (B), $12.30-13.80 \mathrm{~m}$ & $0.332[1](\mathrm{UKAL}-250)$ & $0.297[1](A B E R-1249)$ & LMP \\
\hline Zelzate (B), $12.30-13.80 \mathrm{~m}$ & $0.330 \pm 0.04[4](\mathrm{AAL}-4428)$ & - & LMP \\
\hline 19E117-Noorderhoeve, $43-45 \mathrm{~m}$ & $0.332 \pm 0.009[2](\mathrm{UKAL}-248)$ & - & LMP \\
\hline S01-113 (North Sea), 9-10 m. & $0.303 \pm 0.032[4](\mathrm{UKAL}-258)$ & $0.312 \pm 0.010[5](\mathrm{ABER}-1251)$ & LMP \\
\hline Belvédère & $0.388 \pm 0.014[4]\left(\right.$ ABER-1096) ${ }^{2}$ & - & $\mathbf{B}$ \\
\hline Fransche Kamp & $0.379 \pm 0.03[3](\mathrm{ABER}-1094)^{2}$ & - & $\mathbf{B}$ \\
\hline
\end{tabular}

$\left.{ }^{1}\right)$ = from: Miller $\&$ Mangerud, $1985 ;{ }^{2}$ ) = from: Bates, 1993.

luscan assemblage with Corbicula, belonging to a preEemian temperate stage (Van Kolfschoten, 1981; Meijer, 1991). Bates (1993) published a mean D/L ratio of $0.500 \pm 0.211$ based on Corbicula from Fransche Kamp, which included one very high ratio (0.862). Omission of this anomalous outlier would yield a mean $\mathrm{D} / \mathrm{L}$ ratio of $0.379 \pm 0.03$, which is very close to the Belvédère value.

Shell-bearing Holsteinian deposits are rare in the Netherlands; they are known only from pits in the icepushed hill of Neede and from a neighbouring borehole (34B217-Gelselaar). Both sites provided pollen, mammalian fossils and fluvial molluscan assemblages, the latter including Viviparus diluvianus, Valvata naticina, Parafossarulus crassitesta, Belgrandia marginata, Pisidium clessini but lacking Corbicula.

Combined evidence from Belvédère, Fransche Kamp and Rhenen points to the existence of two temperate intervals before the Saalian ice advance but post-dating the Holsteinian of Neede. These intervals are of interglacial status and can tentatively be correlated with the intra-Saalian Hoogeveen and Bantega interstadials. Amino-acid data (Table 1) suggest a correlation of the Corbicula-bearing beds in the Schouwen Formation with those of 19E117-Noorderhoeve, which occur below Saalian till. These ratios are considerably lower than those obtained from Belvédère and Fransche Kamp. It would seem that the Corbicula beds from the Schouwen Formation and Noorderhoeve can be correlated with those of Rhenen. Corbicula therefore seems to have been present in two pre-Eemian/post-Holsteinian interglacials, a conclusion essentially reached already over fifty years ago (Tesch, 1943) but not fully appreciated by subsequent workers.

The presence of Corbicula in the Eemian type area has already been mentioned. In addition to its occurrence in securely pre-Eemian contexts in borehole 19E117-Noorderhoeve, it has been recovered from marine Eemian deposits from several other boreholes in the same area. In these instances, the Corbicula specimens are always in a preservation state different from that of the associated marine shells. For example, in borehole 24E344-Zunderdorp, an abraded shell of Corbicula occurred alongside a well preserved marine molluscan assemblage, confirmed by aminoacid data as Eemian (Miller \& Mangerud, 1985). Its occurrence in another borehole (19C648-Castricum) in the Eemian type area is, however, harder to explain. Eemian sediments, identified on the basis of their stratigraphical context and their molluscan content, occur in this borehole between $32-43 \mathrm{~m}$ below Dutch Ordnance Datum. They are overlain by Weichselian fluvial and wind-blown sediments, which are in turn buried beneath shallow-marine deposits of Holocene age. Saalian till occurs beneath the Eemian 
sediments at $43 \mathrm{~m}$, so the general sequence is characteristic of that in many boreholes from the western part of the Netherlands.

Miller \& Mangerud (1985) have published aminoacid data from this borehole but additional measurements are now available from two levels within the Eemian deposits: $34.00-35.50 \mathrm{~m}$ and $41-42 \mathrm{~m}$ below Ordnance Datum. The upper level yielded a well preserved molluscan assemblage, consisting of marine species of boreo-temperate affinity and temperate species of non-marine molluscs including Theodoxus fluviatilis. Also present were a large number of warmtemperate marine species of Lusitanian-Mediterranean affinity, that were thought to characterize the Eemian. These specimens, which occurred together with abraded valves of Corbicula are, however, all extremely badly preserved. Between 41 and $42 \mathrm{~m}$ a well preserved assemblage of Ostrea edulis occurs, containing Lusitanian species characteristic of the Eemian but no non-marine taxa or poorly preserved marine molluscs were present. The following amino-acid ratios are available from this Castricum borehole (for an explanation see Table 1):

34-35.50 m: Macoma balthica (well preserved):

$0.162( \pm 0.016)$ [4] (AAL-4223)

Macoma balthica (badly preserved):

$0.216( \pm 0.060)$ [4] (AAL-4224)

Corbicula fluminalis (badly preserved):

0.244 [1] (AAL-4815)

Corbicula fluminalis (badly preserved): 0.210 ( \pm 0.030$)$ [3] (AAL-4429)

41-42 m: Macoma balthica (well preserved): $0.165( \pm 0.020)[4]($ AAL-4227)
The ratios of the well preserved material are consistent with Eemian ratios for Macoma from the Netherlands, whereas the ratios of the badly preserved material point to a pre-Eemian age (Meijer \& Cleveringa, in prep.). These results can easily be explained by reworking of pre-Eemian material into the sample from 34- $35.50 \mathrm{~m}$. This means, however, that many warmtemperate marine species that were previously thought to be characteristic of Eemian deposits in the North Sea Basin, also occur in earlier interglacial deposits. Judging from the amino-acid ratios, this interglacial is identical to that recognized in the Schouwen Formation (Table 1).

In addition to sites on land, Corbicula is known from a large number of offshore boreholes and boxcore samples from the Southern North Sea (Fig. 3). Most boreholes reach a maximum depth of 10-12 m below sea-bed and therefore only penetrate Holocene to Middle Pleistocene deposits. Much of the Corbicula material is associated with marine molluscs that are said to characterize the Eemian, but it is generally badly preserved and probably reworked. In other cases, the Corbicula specimens are better preserved and occur as part of a marine, species-poor assemblage in which Eemian species are missing. Aminoacid data suggest a correlation with the Corbicula-bearing deposits of the Schouwen Formation (Table 1).

The distribution pattern of sites in the Southern North Sea (Fig. 3) needs some explanation. The pattern obviously reflects, in part, the geological mapping programme of the Netherlands Institute for $\mathrm{Ap}-$ plied Geoscience TNO (NITG-TNO), so that the blank regions beyond the Belgian, English and

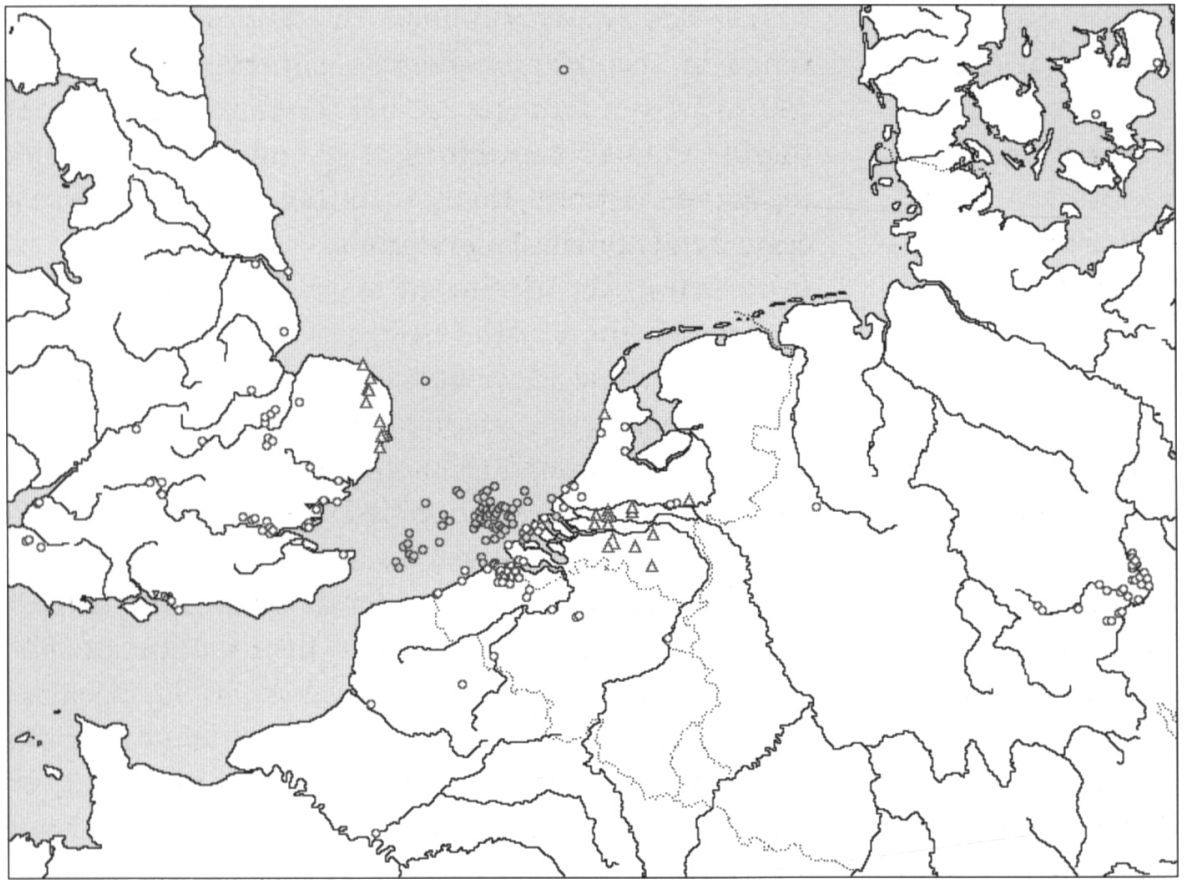

Fig. 3. Distribution of Pleistocene Corbicula in NW Europe. Distribution outside England and the Netherlands is based upon Dollfus (1884), Laville (1898), Johansen (1904), Mourlon (1909), Von Linstow (1922), Halet (1933), De Breuck et al. (1970), Mania (1973), De Moor (1975), De Moor \& Heyse (1975), Miller \& Mangerud (1985) and Roe (1997).

Circles: Middle Pleistocene sites; triangles: Early Pleistocene sites (Tiglian Bavelian). 
French coasts provide no evidence for the presence or absence of Corbicula. On the other hand, the almost straight East-to-West northern limit of the Corbicula area off the Dutch coast does seem to be a genuine feature. North of this boundary, only a few scattered North Sea records of Corbicula are known. Corbicula is commonly washed ashore on North Sea beaches of the SW Netherlands (Van Regteren-Altena, 1937; Moraal, 1961; Janssen et al, 1984) and Eastern England. Much of this material can now be considered to have been reworked from Middle Pleistocene deposits.

\section{Amino-acid racemisation data}

Amino-acid racemization (AAR) data provide independent evidence that can establish the relative ages of particular deposits. Many $\mathrm{D} / \mathrm{L}$ ratios from the study area have already been published and further data on 200 samples from 61 sites in the Netherlands will be published in due time (Meijer \& Cleveringa, in prep.). Many of these ratios have an important bearing on the history of Corbicula (Table 1). Since Corbicula often occurs in estuarine deposits, ratios from the shallow-marine, euryhaline bivalve, Macoma balthica, have also been included.

Three groups of ratios can be distinguished. Ratios from $M$. balthica recovered from Dutch Eemian deposits vary between 0.112 and 0.200 . Molluscan assemblages with similar ratios all lack Corbicula. The data from borehole 15H57-Creil, in the Eemian type area of the central Netherlands, are typical. Both the molluscs and the palynology indicate unambiguously an Eemian age. Corbicula is absent. The ratio from well preserved Macoma shells from a shallow-marine assemblage was amongst the highest yet obtained from a Dutch Eemian deposit (Table 1).

The second well defined group of ratios come from marine assemblages in which both Corbicula and $M a-$ coma occur. Paired ratios on each species were analysed from several samples. The analysed shells from two boreholes (19E117-Noorderhoeve and 6A53-Janum) came from deposits immediately overlain by Saalian till. At Noorderhoeve, a marine Eemian assemblage occurs above the till. The ratios therefore come from contexts that pre-date the Saalian ice advance into this region. At several sites South of the maximum extent of Saalian ice, a Middle Pleistocene deposit occurs, which is overlain by marine Eemian sediments. In the 37C554-Zuurland borehole, for example, sediments yielding an impoverished marine Eemian assemblage overlie fluvial or estuarine sediments of Middle Pleistocene age (Meijer, 1988a). Ratios from Macoma were obtained from both assem- blages; those from the upper one were consistent with an Eemian age, whereas those from the lower were clearly older and attributable to a late Middle Pleistocene interglacial. A similar sequence is present in many boreholes in the bottom of the Southern North Sea. From these, the S01-113 hole is given here as an example (Table 1 ).

The third group of ratios were obtained from specimens of Corbicula recovered from fluvial sediments relating to the Belvédère interglacial. Comparable Corbicula ratios from marine sediments of this age are not yet known. This group is clearly older than the second group of late Middle Pleistocene age.

The badly preserved material from the 19C648Castricum borehole produced ratios that were intermediate between the Eemian and the late Middle Pleistocene group, but we consider them as belonging to the latter.

It thus appears from Dutch amino-acid evidence that Corbicula-bearing beds are all older than the Eemian. Moreover, the data indicate that at least two groups of ratios can be distinguished in the Dutch late Middle Pleistocene.

\section{Conclusions and discussion}

The systematics of Corbicula are urgently in need of revision but it would appear that only one polymorphic species (Corbicula fluminalis) occurred in the Pleistocene of NW Europe. It was present only during temperate stages, although its occurrence should not automatically been taken to infer thermal optimum conditions. Its absence during the early parts of several interglacial stages, when climatic conditions were optimal, can probably been attributed to migrational failure. Similarly its persistence towards the end of several interglacials shows some tolerance of slightly cooler conditions. Although principally a fresh-water species, there is evidence that it could tolerate mildly brackish conditions.

Its history in NW Europe can be traced back to the Pliocene. It occurred in most of the temperate stages of the Early Pleistocene (Tiglian - Bavelian) but there are no authentic records of it from the 'Cromerian Complex' in either Britain or the Netherlands. It has been found in the sediments of three successive interglacials after the Anglian, but it appears to have been absent in the Ipswichian in Britain and the Eemian in the Netherlands. Likewise it is unknown as a Holocene fossil in NW Europe, but the genus has been reintroduced to Europe during the last twenty years. It is presently undergoing a rapid expansion of its geographical range, taking only four years, for example, to spread throughout much of the Rhine system. Live 
specimens have recently been found in Norfolk (Howlett \& Baker, 1999) and its rapid spread through the inland waterways of East Anglia seems imminent, unless remedial measures are taken immediately. Corbicula possesses several important attributes for a successful colonizer and the rapidity of its recent invasion provides an insight into the probable nature of its spread during the Middle Pleistocene.

In 1964 the late Bruce Sparks published a review of the non-marine molluscs known from the last interglacial in South-East England. He listed some 125 species of non-marine molluscs known from ten sites believed to date from the last interglacial (Ipswichian). He thought that 'new work seems likely to add only in detail to our present knowledge'. It now seems that most of the sites he believed to date from the last interglacial do, in fact, belong to older interglacial stages. The same situation is likely to be true for many continental sites previously attributed to the Eemian. Sites with Corbicula that have been assigned to the last interglacial deserve special scrutiny, although attribution to older stages must not rely solely on the occurrence of Corbicula, if circular reasoning is to be avoided. Only when such sites have been critically evaluated in the light of new understanding about the complexity of the interglacial record following the Anglian/Elsterian, will it be possible to gain a true picture of life during the last interglacial.

\section{Acknowledgements}

We thank David Bridgland, Piet Cleveringa, Philip Gibbard, John Hollin, David Keen and Danielle Schreve for discussion about points raised in the present contribution. David Bridgland and Gijs Peeters kindly allowed us to use figures from their work.

\section{References}

Allen, T., 1977. Interglacial sea-level change: evidence for brackish water sedimentation at Purfleet, Essex. Quaternary Newsletter 22: 1-3.

Baden-Powell, D.F.W., 1934. On the marine gravels at March, Cambridgeshire. Geological Magazine 71: 193-219.

Bates, M.R., 1993. Preliminary amino acid epimerization age estimates from the Maastricht-Belvédère and Wageningen-Fransche Kamp sites in The Netherlands (a short note). Mededelingen Rijks Geologische Dienst 47: 47-49.

Bell, A., 1871. Contributions to the Crag fauna. Annals and Magazine of Natural History 7: 351.

Bennema, J. \& Pons, L.J., 1952. Donken, fluviatiel laagterras en Eemzee-afzettingen in het Westelijk gebied van de grote rivieren. Boor en Spade 5: 126-137.

Blanken, E., 1990. Corbicula fluminalis Müller, 1774 nieuw in $\mathrm{Ne}-$ derland. Correspondentieblad van de Nederlandse Malacologische Vereniging 252: 631-632.

Bowen, D.Q., Hughes, S., Sykes, G.A. \& Miller, G.H., 1989. Land- sea correlations in the Pleistocene based on isoleucine epimerization in non-marine molluscs. Nature 340: 49-51.

Bridgland, D.R., 1994. Quaternary of the Thames. Geological Conservation Review Series 7. Chapman \& Hall (London): 441 pp.

Bridgland, D.R., 1995. The Quaternary sequence of the eastern Thames basin: problems of correlation. In: Bridgland, D.R., Allen, P. \& Haggart, B.A. (eds.): The Quaternary of the lower reaches of the Thames. Quaternary Research Association Field Guide: 35- 52 .

Bridgland, D.R., Preece, R.C., Roe, H.M., Tipping, R.M., Coope, G.R., Field, M.H., Robinson, J.E., Schreve, D.C. \& Crowe, K. (submitted). Middle Pleistocene interglacial deposits at Barling, Essex, UK: evidence for a longer chronology for the Thames terrace sequence. Journal of Quaternary Science.

Briggs, D.J., Coope, G.R. \& Gilbertson, D.D., 1985. The chronology and environmental framework of early Man in the Upper Thames Valley: a new model. British Archaeological Report, British Series 137: 176 pp.

Britton, J.C. \& Morton, B., 1979. Corbicula in North America: the evidence reviewed and evaluated. pp 249-287. In: Britton, J.C. (ed.): Proceedings of the First International Corbicula symposium (Texas Christian University Research Foundation, Fort Worth, Texas, U.S.A.): 313 pp.

Britton, J.C. \& Morton, B., 1986. Polymorphism in Corbicula fluminea (Bivalvia: Corbiculidae) from North America. Malacological Review 19: 1-43.

Buckingham, C.M., Roe, D.A. \& Scott, K., 1996. A preliminary report on the Stanton Harcourt Channel Deposits (Oxfordshire, England); geological context, vertebrate remains and palaeolithic stone artefacts. Journal of Quaternary Science 11: 397-415.

Connolly, M., 1930. Descriptions of new molluscs from Central Africa with notes on other species. Proceedings of the Malacological Society of London 19: 37-48.

De Breuck, W., De Moor, G. \& Marechal, R., 1970. Lithostratigrafie van de Kwartaire sedimenten in het Oostelijk kustgebied (België). Natuurwetenschappelijk Tijdschrift 51(1969): 125-137.

De Gans, W. \& De Groot, T. 1995a. Oude Leede (Pleistocene and early Holocene fluvial systems). In: Schirmer, W. (ed.): Quaternary field trips in Central Europe, 1: Regional field trips, INQUA, XIV International Congress, Berlin. F. Pfeil (München): 553-554.

De Gans, W. \& De Groot, T., 1995b. Hook of Holland (Reworked Pleistocene marine deposits). In: Schirmer, W. (ed.): Quaternary field trips in Central Europe, 1: Regional field trips, INQUA, XIV International Congress, Berlin. F. Pfeil (München): 554-555.

Den Hartog, C., Van den Brink, F.W.B. \& Van der Velde, G., 1992. Why was the invasion of the river Rhine by Corophium curvispinum and Corbicula species so successful? Journal of Natural History 26: 1121-1129.

De Jong, J., 1988. Palynological investigation of the Zuurland-2 borehole, The Netherlands (an interim report). Mededelingen van de Werkgroep voor Tertiaire en Kwartaire Geologie 25: 31 38.

De Jong, J. \& Zagwijn, W.H., 1983. De vegetatiegeschiedenis van 's-Gravenhage en omgeving. Mededelingen Rijks Geologische Dienst 37: 44-62.

De Moor, G., 1975. De afzetting van Dendermonde en haar betekenis voor de jong-kwartaire evolutie van de Vlaamse Vallei. Natuurwetenschappelijk'Tijdschrift 56: 45-75.

De Moor, G. \& Heyse, I., 1975. Litostratigrafie van de kwartaire afzettingen in de overgangszone tussen de kustvlakte en de Vlaamse Vallei in Noordwest-België. Natuurwetenschappelijk Tijdschrift 56: 85-109.

Dollfus, G.-F., 1884. Le terrain Quaternaire d'Ostende et le Corbi- 
cula fluminalis (Müller species). Mémoires de la Société royale de Malacologie de la Belgique 19:29 pp.

Ellis, A.E., 1978. British freshwater bivalve molluscs. Synopses of the British fauna (New Series) 11. Linnean Society of London / Academic Press: 109 pp.

Gardner, E.W., 1932. Some lacustrine Mollusca from the Faiyum Depression. A study in variation. Mémoires de l'Institut d'Egypt (Le Caire) 18, XVI: 1-114

Gibbard, P.L., 1994. Pleistocene history of the Lower Thames Valley. Cambridge University Press (Cambridge): $221 \mathrm{pp}$.

Gibbard, P.L., 1995. Palaeogeographical evolution of the Lower Thames Valley. In: Bridgland, D.R., Allen, P. \& Haggart, B.A. (eds.): The Quaternary of the lower reaches of the Thames. Quaternary Research Association Field Guide: 5-34.

Gittenberger, E., Janssen, A.W., Kuijper, W.J., Kuiper, J.G.J., Meijer, T., Van der Velde, G. \& De Vries, J.N., 1998. De Nederlandse zoetwatermollusken. Recente en fossiele weekdieren uit zoet en brak water. Nederlandse Fauna 2. Nationaal Natuurhistorisch Museum Naturalis, KNNV Uitgeverij \& EIS-Nederland (Leiden): $288 \mathrm{pp}$.

Halet, F., 1933. Sur la présence de couches à Corbicula fluminalis Müller aux environs de Saint-Denis-Westrem. Bulletin de la Société belge de Géologie, de Paléontologie et d'Hydrologie, 43: 111-116.

Hinton, M.A.C. \& Kennard, A.S., 1900. Contributions to the Pleistocene geology of the Thames Valley. I. The Grays Thurrock area, part 1. Essex Naturalist 11:336-370.

Hollin, J.T., 1977. Thames interglacial sites, Ipswichian sea levels and Antarctic ice surges. Boreas 6: 33-52.

Howlett, D. \& Baker, R., 1999. Corbicula fluminea (Müller): new to U.K. Journal of Conchology 36: 83.

Janssen, A.W., 1965. Mollusca uit de Pleistocene ontsluiting te Zelzate. Mededelingen van de Werkgroep voor Tertiaire en Kwartaire Geologie 2: 24-37.

Janssen, A.W., Peeters, G.A. \& Van der Slik, L., 1984. De fossiele schelpen van de Nederlandse stranden en zeegaten, tweede serie, 8 (slot). Basteria 48: 89-220.

Johansen, A.C., 1904. Om den fossile kvartaere molluskfauna i Danmark og dens relationer til forandringer i klimaet. Land- og ferskvandsmolluskfaunaen (København) I-IV: 1-136.

Keen, D.H., 1990. Significance of the record provided by Pleistocene fluvial deposits and their included molluscan faunas for palaeoenvironmental reconstruction and stratigraphy: case study from the English Midlands. Palaeogeography Palaeoclimatology Palaeoecology 80: 25-34.

Kennard, A.S. \& Woodward, B.B., 1919. The non-marine Mollusca of the Cambridgeshire gravels. Quarterly Journal of the Geological Society of London 75: 229-241.

Kennard, A.S. \& Woodward, B.B., 1922. The post-Pliocene nonmarine Mollusca of the East of England. Proceedings of the Geologists' Association 33: 104-142.

Kennard, A.S. \& Woodward, B.B., 1924. Appendix III. The Pleistocene non-marine Mollusca pp 170-175. In: Sandford, K.S.: The river gravels of the Oxford district. Quarterly Journal of the Geological Society of London 80: 113-179.

Kennard, A.S. \& Woodward, B.B., 1926. Note on O.F. Müller's types of Tellina fluminalis, fluminea and fluviatilis. Proceedings of the Malacological Society of London 17:100-101.

Kerney, M.P., 1959. Pleistocene non-marine Mollusca of the English interglacial deposits. Unpublished Ph.D. thesis University of London: $403 \mathrm{pp}$.

Kerney, M.P., 1971. Interglacial deposits at Barnfield pit, Swanscombe, and their molluscan fauna. Journal of the Geological Society of London 127: 69-93.

Kinzelbach, R., 1991. Die Körbchenmuscheln Corbicula fluminalis,
Corbicula fluminea und Corbicula fluviatilis in Europa (Bivalvia: Corbiculidae). Mainzer Naturwissenschaftliches Archiv 29: 215 228.

Laville, A., 1898. Le gisement Chelléo-Moustiérien à Corbicules de Cergy. Bulletin de la Société d'Anthropologie de Paris 9: 57-70.

Lorié, J., 1913. Beschrijving van eenige nieuwe grondboringen, VIII. Mededeelingen omtrent de geologie van Nederland, verzameld door de commissie voor het geologisch onderzoek, no. 38 . Verhandelingen der Koninklijke Akademie van Wetenschappen te Amsterdam 17: 3-65.

Maddy, D., Keen, D.H., Bridgland, D.R, \& Green, C.P., 1991. A revised model for the Pleistocene development of the River Avon, Warwickshire. Journal of the Geological Society of London 148: 473-484.

Mania, D., 1973. Paläoökologie, Faunenentwicklung und Stratigraphie des Eiszeitalters im mittleren Elbe-Saalegebiet auf Grund von Molluskengesellschaften. Geologie 21, Beiheft 78/79: 1-175.

Marr, J.E., 1917. Submergence and glacial climates during the accumulation of the Cambridgeshire Pleistocene deposits. Proceedings of the Cambridge Philosophical Society 14:64-71.

Meijer, T., 1969. Theodoxus danubialis (Pfeiffer 1828) uit de Vlaamse Vallei te Zelzate (België). Mededelingen van de Werkgroep voor Tertiaire en Kwartaire Geologie 6: 53-54.

Meijer, T., 1985. The pre-Weichselian non-marine molluscan fauna from Maastricht-Belvédère (Southern Limburg, The Netherlands). Mededelingen Rijks Geologische Dienst 39: 75-103.

Meijer, T., 1987. De Molluskenfauna van het Waalien in Nederland. Correspondentieblad van de Nederlandse Malacologische Vereniging 236: 276-279 + 237: 288-297.

Meijer, T., 1988a. Mollusca from the borehole Zuurland-2 at Brielle, The Netherlands (an interim report). Mededelingen van de Werkgroep voor Tertiaire en Kwartaire Geologie 25: 49-60.

Meijer, T., 1988b. Fossiele zoetwaternerieten uit het Nederlandse Kwartair en enkele opmerkingen over het voorkomen van deze groep in het Kwartair van Noordwest Europa. De Kreukel, Jubileumnummer: 89-108.

Meijer, T., 1990. Notes on Quaternary freshwater Mollusca of the Netherlands, with descriptions of some new species. Mededelingen van de Werkgroep voor Tertiaire en Kwartaire Geologie 26: 145-181.

Meijer, T., 1991. Molluscan investigation of ice-pushed Pleistocene deposits near Wageningen, The Netherlands. Mededelingen Rijks Geologische Dienst 46: 55-64.

Meijer, T. \& Cleveringa, P. (in prep.). Aminostratigraphy of Middle and Late Pleistocene deposits in the Netherlands. Quaternary Science Reviews.

Meijer, T. \& Preece, R.C., 1995. Malacological evidence relating to the insularity of the British Isles during the Quaternary. In: Preece, R.C. (ed.): Island Britain: a Quaternary perspective. Geological Society Special Publication 96: 89-1 10.

Meijer, T. \& Preece, R.C., 1996. Malacological evidence relating to the stratigraphical position of the Cromerian. In: Turner, C. (ed.): The early Middle Pleistocene of Europe. Balkema (Rotterdam): 53-82.

Mienis, H.K., 1991. Some remarks concerning Asiatic clams invading Europe with a note on sample of Corbicula fluminea (Müller, 1774) from Trapani, Sicily. Notiziario SIM 9: 137-139.

Miller, G.H. \& Mangerud, J., 1985. Aminostratigraphy of European marine interglacial deposits. Quaternary Science Reviews 4: 217-278.

Moolenbeek, R., 1993. Problemen rond de naamgeving van de Aziatische korfmossel, de fijngeribde korfmossel en de toegeknepen korfmossel, ofwel de Corbicula's in Nederland. Correspondentieblad van de Nederlandse Malacologische Vereniging 270: 1921 . 
Moraal, J.M., 1961. Een fossiele zoetwaterschelp van de Zeeuwse stranden. Grondboor en Hamer, Nieuwe Serie 9: 250-253.

Morton, B., 1986. Corbicula in Asia - an updated synthesis. American Malacological Bulletin, Special Edition 2: 113-124.

Mourlon, M., 1909. Découverte d'un dépôt quaternaire campinien avec faune du Mammouth et débris végétaux dans les déblais profonds d'Hofstade, à l'est Sempst (Brabant Belge). Bulletin de l'Académie Royale de la Belgique, (Classe des Sciences) 4: 427-434.

Mouthon, J., 1981. Sur la présence en France et au Portugal de Corbicula (Bivalvia, Corbiculidae) originaire d'Asie. Basteria 45: 109-116.

Müller, O.F., 1774. Vermium terrestrium et fluviatilium, seu animalium Infusoriorum, Helminthicorum et Testaceorum, non marinorum succincta historia 2 : XXXVI $+214 \mathrm{pp}$. (Mavniae et Lipsiae).

Nyst, P.H., 1838. Notice sur une Cyrène et sur une Cancellaire inédites. Bulletin de la Commission Royale d'Histoire/Académie Royale de Belgique 5: 113-116.

Preece, R.C., 1995. Mollusca from interglacial sediments at three critical sites in the Lower Thames. In: Bridgland, D.R., Allen, P. \& Haggart, B.A. (eds.): The Quaternary of the lower reaches of the Thames. Quaternary Research Association Field Guide: 5360.

Preece, R.C., 1999. Mollusca from last interglacial fluvial deposits of the River Thames at Trafalgar Square, London. Journal of Quaternary Science 14: 77-89.

Roe, H.M., 1997. Shelf database. The Northwest European continental shelf over the past 250.000 years; Contract no: EV5VCT93-0255.

Roe, H.M., 1999. Late Middle Pleistocene sea-level change in the southern North Sea: the record from eastern Essex, UK. Quaternary International 55: 115-128.

Roe, H.M. \& Preece, R.C., 1995. A new discovery of the Middle Pleistocene 'Rhenish' fauna in Essex. Journal of Conchology 35 : 272-273.

Rowe, P.J., Atkinson, T.C. \& Turner, C., 1999. U-series dating of Hoxnian interglacial deposits at Marks Tey, Essex, England. Journal of Quaternary Science 14: 693-702.

Ruegg, G.H.J. (ed.), 1991. Geology and archaeology of ice-pushed Pleistocene deposits near Wageningen (The Netherlands). Mededelingen Rijks Geologische Dienst 46: 99 pp.

Ruegg, G.H.J. \& Zandstra, J.G. (eds.), 1981. Geology and archaeology of Pleistocene deposits in the ice-pushed ridge near Rhenen and Veenendaal. Mededelingen Rijks Geologische Dienst 35: 163-268.

Sandford, K.S., 1925. The fossil elephants of the Upper Thames Basin. Quarterly Journal of the Geological Society of London 81: 62-86.

Sarntheim, M., Stremme, H.E. \& Mangini, A., 1986. The Holstein Interglaciation: time-stratigraphic position and correlation to stable-isotope stratigraphy of deep-sea sediments. Quaternary Research 26: 283-298.

Schlickum, W.R., Puisségur, J.J. \& Clair, A., 1978. Die Molluskenfauna der Schichten mit Viviparus burgundinus und Pyrgula nodotiana von Montagny-les-Beaune (Dép. Côte-d’Or). Archiv für Molluskenkunde 109: 1-26.

Schreve, D.C., 1997. Mammalian biostratigraphy of the later Middle Pleistocene in Britain. Unpublished Ph.D. thesis University of London: $776 \mathrm{pp}$.

Shackleton, N.J. \& Opdyke, N. D., 1973. Oxygen isotope and palaeomagnetic stratigraphy of equatorial Pacific core V28-238: oxygen isotope temperatures and ice volume on a $10^{5}$ year and $10^{6}$ year scale. Quaternary Research 3: 39-55.

Shotton, F.W., Banham, P.H. \& Bishop, W.W., 1977. Glacial-interglacial stratigraphy of the Quaternary in Midland and eastern
England. In: Shotton, F.W. (ed.): British Quaternary studies: recent advances. Clarendon Press (Oxford): 267-282.

Spaink, G., 1968. Een bijzondere continentale molluskenfauna uit het Oud Pleistoceen uit een kleigroeve tussen Bavel en Dorst nabij Breda. Correspondentieblad van de Nederlandse Malacologische Vereniging 129: 1382-1384.

Sparks, B.W., 1964. The distribution of non-marine Mollusca in the Last interglacial in south-east England. Proceedings of the Malacological Society of London 36: 7-25.

Sparks, B.W. \& West, R.G., 1964. The interglacial deposits at Stutton, Suffolk. Proceedings of the Geologists' Association 74: 419432 ,

Steenhuis, J.F,, 1915. Rapport omtrent de geologische resultaten van het geo-hydrologisch onderzoek, verricht ten behoeve van het opmaken der plannen voor de centrale drinkwatervoorziening in Zuidholland, Noordholland en Utrecht (CDV). Bijlage 1: uitgewerkt rapport betreffende de centrale drinkwatervoorziening in Zuidholland, Noordholland en Utrecht. Rijksbureau voor Drinkwatervoorziening (Den Haag) 6:80 pp.

Steenhuis, J.F., 1919. De geologische bouw en geschiedenis van den ondergrond van het eiland Walcheren. Rapport betreffende een centrale drinkwatervoorziening van het eiland Walcheren, appendix II: 7-68. Internal Report Rijksbureau voor Drinkwatervoorziening ('s-Gravenhage): $68 \mathrm{pp}$.

Stuart, A.J., 1976. The history of the mammal fauna during the Ipswichian/last interglacial in England. Philosophical Transactions of the Royal Society B 276: 221-250.

Sutcliffe, A.J., 1964. The mammalian fauna. In: Ovey, C.D. (ed.): The Swanscombe skull: a survey of research on a Pleistocene site. Royal Anthropological Institute, Occasional Paper 20: 85111.

Sutcliffe, A.J., 1975. A hazard in the interpretation of glacial-interglacial sequences. Quaternary Newsletter 17: 1-3.

Sutcliffe, A.J., 1976. The British glacial-interglacial sequence - reply to R.G. West. Quaternary Newsletter 18: 1-7.

Sutcliffe, A.J., 1995. Insularity of the British Isles 250 000-30000 years ago: the mammalian, including human, evidence. In. Preece, R.C. (ed.): Island Britain: a Quaternary perspective. Geological Society Special Publication 96: 127-140.

Tesch, P., 1929a. De stratigrafische grens Plioceen-Plistoceen in Europa. Geologisch-Mijnbouwkundig Genootschap voor Nederland en Koloniën. Verslagen der Geologische Sectie 3: 203-211.

Tesch, P., 1929b. Lijst der land- en zoetwatermolluscen aangetroffen in de Kwartaire lagen in Nederland. Mededelingen. Rijks Geologische Dienst A(3): V + $32 \mathrm{pp}$.

Tesch, P., 1939. De mariene inschakeling in de 'Hoogterrasafzettingen' in het Westen en Noorden van Nederland. Geologie en Mijnbouw 1:9-13.

Tesch, P., 1943. Corbicula fluminalis als gidsfossiel. Jaarverslag Geologische Stichting 1941: 31-33.

Tesch, P., 1944. Nieuwe lijst der Kwartaire land- en zoetwatermollusken in Nederland. Mededelingen. Rijks Geologische Dienst A 10:24 pp.

Tomlinson, M.E., 1925. River-terraces of the Lower Valley of the Warwickshire Avon. Quarterly Journal of the Geological Society of London 81: 137-163.

Turner, C. \& Kerney, M.P., 1971. A note on the age of the freshwater beds of the Clacton Channel. Journal of the Geological Society of London 127: 87-93.

Tzedakis, P.C., Andrieu, V., De Beaulieu, J.-L., Crowhurst, S., Follieri, M., Hooghiemstra, H., Magri, D., Reille, M., Sadori, L., Shackleton, N.J. \& Wijmstra, T.A., 1997. Comparison of terrestrial and marine records of changing climate of the last 500,000 years. Earth and Planetary Science Letters 150: 171-176.

Van Damme, D., 1984. The freshwater Mollusca of northern 
Africa: distribution, biogeography and palaeoecology. Developments in Hydrobiology 25. Dr W. Junk Publishers (Dordrecht): $164 \mathrm{pp}$.

Van den Berg, M.W., 1996. Fluvial sequences of the Maas: a $10 \mathrm{Ma}$ record of neotectonics and climatic change at various timescales. Ph.D. thesis University Wageningen: $181 \mathrm{pp}$.

Vandenberghe, J., Roebroeks, W. \& Van Kolfschoten, Th. (eds.), 1993. Maastricht-Belvédère: stratigraphy, palaeoenvironment and archaeology of the Middle and Late Pleistocene deposits, Part II. Mededelingen Rijks Geologische Dienst 47: $91 \mathrm{pp}$.

Van der Heide, S., 1957. Correlations of marine horizons in the Middle and Upper Pleistocene of the Netherlands. Geologie en Mijnbouw 19: 272-276.

Van der Sleen, W.G.N., 1912. Bijdrage tot de kennis der chemische samenstelling van het duinwater in verband met de geomineralogische gesteldheid van den bodem. Ph.D. thesis Universiteit Amsterdam: XVI + $157 \mathrm{pp}$.

Van Kolfschoten, Th, 1981. On the Holsteinian? and Saalian mammal fauna from the ice-pushed ridge near Rhenen (The Netherlands). Mededelingen Rijks Geologische Dienst 35: 223-251.

Van Kolfschoten, T., 1985. The Middle Pleistocene (Saalian) and Late Pleistocene (Weichselian) mammal faunas from Maastricht-Belvédère, (Southern Limburg, The Netherlands). Mededelingen Rijks Geologische Dienst 39: 45-74.

Van Kolfschoten, Th., 1993. The mammal fauna from the interglacial deposits at Maastricht-Belvédère. Mededelingen Rijks Geologische Dienst 47: 51-60.

Van Kolfschoten, Th. \& De Boer, P.L. (eds.), 1988. The Zuurland2 borehole. Mededelingen van de Werkgroep voor Tertiaire en Kwartaire Geologie 25: 106 pp.

Van Kolfschoten, Th. \& Roebroeks, W., 1985. MaastrichtBelvédère: stratigraphy, palacoenvironment and archaeology of the Middle and Late Pleistocene deposits. Mededelingen Rijks Geologische Dienst 39: 1-121.

Van Kolfschoten, Th., Roebroeks, W. \& Vandenberghe, J., 1993. The Middle and Late Pleistocene sedimentary and climate se- quence at Maastricht-Belvedère: the type locality of the Belvédère interglacial. Mededelingen Rijks Geologische Dienst 47: 81-91.

Van Regteren-Altena, C.O., 1937. Bijdrage tot de kennis der subfossiele en recente mollusken, die op de Nederlandse stranden aanspoelen, en hunner verspreiding. Nieuwe Verhandelingen van het Bataafs Genootschap voor Proefondervindelijke Wijsbegeerte, $2^{\mathrm{c}}$ Reeks 10 (3): $184 \mathrm{pp}$.

Van Rummelen, F.F.F.E., 1970. Blad Schouwen-Duiveland. Toelichting bij de Geologische Kaart van Nederland 1: 50.000 . Rijks Geologische Dienst (Haarlem): 116 pp.

Von Linstow, O., 1922. Beitrag zur Geschichte und Verbreitung von Corbicula fluminalis. Archiv für Molluskenkunde 54: 113-144.

West, R.G., 1969. Pollen analyses from interglacial deposits at Aveley and Grays. Proceedings of the Geologists' Association 80: 271-282.

West, R.G., Sparks, B.W. \& Lambert, C.A., 1964. Interglacial deposits at Ilford, Essex. Philosophical Transactions of the Royal Society B 247: 185-212.

West, R.G., Knudsen, K.L., Penney, D.N., Preece, R.C. \& Robinson, J.E., 1994. Palaeontology and taphonomy of Late Quaternary fossil assemblages at Somersham, Cambridgeshire, UK, and the problem of reworking. Journal of Quaternary Science 9: 357-366.

Wood, 1834. Lacustrine formations, among the Tertiary Beds [of East Anglia]. Magazine of Natural History 7: 274-275.

Worssam, B.C. \& Taylor, J.H., 1969. Geology of the country around Cambridge. Memoirs of the Geological Survey of Great Britain, England \& Wales. HMSO (London): 159 pp.

Zagwijn, W.H. \& Paepe, R., 1968. Die Stratigraphie der Weichselzeitlichen Ablagerungen der Niederlande und Belgien. Eiszeitalter und Gegenwart 19:129-146.

Zeuner, F.E., 1959. The Pleistocene period: its climate, chronology and faunal successions. Hutchinson Scientific \& Technical (London). 